\title{
INTERPERSONAL CONFLICT - HANDLING STYLES USED IN PUBLIC AND PRIVATE SECTOR ORGANISATIONS: A COMPARATIVE STUDY
}

\author{
WERNER HAVENGA \\ wh@rau.ac.za \\ Department of Human Resource management \\ University of Johannesburg \\ JAN VISAGIE \\ bsojvc@puknet.puk.ac.za \\ School for Human Resources Sciences \\ North-West University
}

\begin{abstract}
The objective of this study was to determine and compare by means of an empirical study whether there exists a significant difference in the handling of interpersonal conflict between two totally different organizations. The study made use of the Rahim Organizational Conflict Inventory - ROC-II instrument to determine the extent of usage of five conflict handling styles by employees of an agricultural company and a local authority. Results indicated that a significant difference exists in usage of the various handling styles between respondents and their superiors as well as respondents and their peers. The obliging style and integrating styles were used the most and the dominating style was used the least in both organisations. Significant differences were also recorded with regard to sex, age and qualifications and the usage of different conflict handling styles. These results have definite implications for managing conflict in organizations.
\end{abstract}

\section{OPSOMMING}

Die doelwit van hierdie studie was om d.m.v 'n empiriese studie vas te stel en te vergelyk of daar 'n betekenisvolle verskil is in die hantering van interpersoonlike konflik tussen twee verskillende organisasies. Die studie het gebruik gemaak van die Rahim Organizational Conflict Inventory - ROC II instrument om vas te stel watter mate die vyf konflikhantering-style binne 'n landboumaatskappy en 'n plaaslike owerheid, gebruik word. Resultate het gewys dat daar ' $n$ betekenisvolle verskil is in hanteringstyle tussen respondente en hul hoofde sowel as respondente en hul gelykes. Die toegewende- en integrerende styl was die meeste gebruik en die dominerende styl die minste in beide organisasies. Betekenisvolle verskille is ook aangeteken met betrekking tot geslag, ouderdom en kwalifikasies en die gebruik van die verskillende konflikhantering-style. Hierdie resultate hou noemenswaardige implikasies in vir die bestuur van konflik in organisasies.

The organisational network, is composed of individual parties together with their individual mutual relations. Regarding individual parties (subunits, individuals, groups) the interactional dynamics may manifest differently in different contexts. Furthermore, the task-oriented and socio-emotional relational aspects are combined with relational aspects involving power and the allocation of scarce resources (Mastenbroek, 1993:13). These relational aspects whether in groups or individuals very often result in situations of conflict which can have a negative influence on an effective working environment (McNamara, 2003) or beneficial to groups and organisations (Bodtker \& Jameson, 2001). Tjosvold \& Chia (1988) recognized that poorly handled conflict tends to reduce productivity and increase labour relations problems. It was also shown by Jehn (1997) that as an individual becomes emotional during conflict he or she loses focus on tasks, becomes less effective resulting in lack of performance. Pelled, Eisenhardt \& Xin (1999) concluded that organisational conflict has both functional (positive) outcomes of conflict include; better ideas are produced; people are forced to clarify their ideas; interest and creativity are stimulated; and other people capacities are tested. Studies of Opotow (2000) again stresses aggression as a very important consequence of dysfunctional conflict.

Inadequate or excessive levels of conflict hinder the effectiveness of a group, individual or organisation, resulting in group members to be less stratified, increased absence and turnover rates, and eventually lower in productivity. On the other hand, when conflict is at an optimal level, complacency and apathy should be minimised, motivation should be enhanced through the creation of a challenging and questioning environment with a vitality that makes work interesting (Robbins, Odendaal \& Roodt, 2003).
Estimates by Nelson \& Quick (2001) reveal that approximately 21 percent of managers' time is spend on managing conflict. It should be noted that a difference exists between the concepts "conflict handling", "conflict resolution" and "conflict management" (Schermerhorn, 1999). For purposes of this article conflict management and conflict handling will be recognized as synonymous. Rahim (1992; 2002) and Thomas \& Killman (1974; 1976) who pioneered studies on conflict-handling styles clearly distinguish between conflict resolution on the one side and handling or managing conflict on the other side. Rahim \& Bonoma (1979) differentiated the styles of handling conflict on two basic dimensions: concern for self and concern for others. Van de Vliert and Kabanoff (1990) were in general support for these two dimensions. Combination of the two dimensions results in five specific styles of handling (CHS) interpersonal conflict i.e.: Rahim (2002)

- Integrating: Focuses on problem-solving in a collaborative fashion. High concern for self and others.

- Obliging: Involves low concern for self as well as other party. Inaction, withdrawal or ignoring.

- Dominating: High concern for self and low concern for opposing party. Control, competing, zero-sum, win-lose.

- Compromising: Moderate concern for self as well as other party. Give-and-take or sharing.

- Avoiding: Low concern for self as well as other party. Inaction, withdrawal or ignoring.

More recent studies have narrowed down or broadened the number of styles to adaptive, forcing, avoiding, abusive (Meyer, 2004), and forcing, confronting, avoiding, compromising, accommodating, problem solving and press controlling (Euwema, Van de Vliert \& Bakher, 2003). For purposes of this study the five conflict handling styles of Rahim were used. 


\section{RESEARCH DESIGN}

\section{Research approach}

In order to manage or handle conflict effectively, cognisance should be taken of the role elements such as communication, emotions, culture supremacy aspirations and 'conflict management styles. It can be contended by doing so, it may open opportunities for using generic conflict management strategies in the work environment. One should consider that the amount, intensity and positive or negative impact of conflict at present and in future is a function of the way in which conflict is handled by the individual. Considering organisational changes, affirmative action programmes, scarce resources, management changes and behavioural processes within public and private sector organisations, it is believed that conflict potential may be increasing within these sectors of the South African economy. Conflict between personnel on both horizontal and vertical levels can no longer be ignored or left unattended. In the South African context, limited information is available concerning local authorities and private sector businesses' understanding of conflict and the styles used by parties to manage it.

No studies were found in which the relationship between a profit and non-profit institutions' usage of the different conflict handling styles were explored simultaneously. This study addresses the research question: Assuming that conflict does exist within two totally different organisations, functioning in totally different economic environments, is there a significant difference in conflict management styles being used?

In order to answer this question the objective of this article is to determine and compare by means of an empirical based study whether there is a significant difference in the handling of interpersonal conflict.

\section{Research Methodology}

The measuring instrument used in the study is a conflictevaluating questionnaire. It consists of a standardized (Rahim Organizational Conflict Inventory - ROC II) part and a section designed to measure and test elements not included in the standardized sections of the questionnaire. Rahim \& Magner (1995) performed confirmatory factor analysis with five different samples that provide support for the convergent and discriminate validities of the ROC-II and the invariance of the five-factor model across referent roles, that is supervisors (superiors), subordinates and peers, organizational levels, that is, top, middle, lower and non-management (operational).

Pre-testing were conducted amongst colleagues, managers of human resource departments and personnel of both participating organisations and staff members of the Statistical Support Services division of two universities to ensure validity of the research instrument.

\section{Sample}

Data for this study were collected using the survey methodology. Samples were drawn from both a local authority and an agriculture company's top-, and middle management and operational levels.

A stratified random sample of employees from operational (joblevel 13) up to the top-level management (job-level 1) were taken in a local authority. This sample represents the total population of all the directorates, genders, ages and races. Of the total population of 386 employees 193 employees were selected randomly of which 143 questionnaires were returned. $72 \%(\mathrm{~N}=$ 139) were usable questionnaires and can be considered an adequate sample size for statistical analysis (Hair, G.E., \& Anderson, R.E., 1995).

The sample taken from job-levels 5 to 16 in the agriculture company also included the executive management above level
16. Similar to the local authority the total population of all departments included persons from all departments, ages, genders and races. The total population of 101 formed the total sample (100\%). The number returned was 65 of which 64 $(63,4 \%)$ could be used. Because a sample can never reflect its population for certain, researchers must determine how much precision they need (Emory \& Cooper, 1991). It is believed that both samples can be considered adequate to justify correct statistical analysis for purpose of this study.

The directorates of the Human Resources Departments of both participating were responsible for distribution to, briefing of respondents and recovering of the questionnaires.

\section{Biographical data}

In table 1 gender comparison reveals that $74,6 \%$ and $37,5 \%$ of the respondents in both organizations were male. Age distribution recorded in three categories ranged between $34,5 \%$ - 33,1\% and $28,6 \%$ - 33,3\% which represents an almost equal distribution of respondents. In the case of the local authority a much larger percentage $(43,9 \%)$ of respondents had some form of tertiary education. Number of years service revealed that $50 \%$ of the local authority employees had 11 years or more. In the case of the agriculture company the figure was $54,7 \%$. Only $56.1 \%$ of the respondents' in the local authority spoke Afrikaans at home, whilst in the case of the agriculture company the percentage was $90,6 \%$

TABLE 1

RESPONDENT' BIOGRAPHICAL DETAILS

\begin{tabular}{|c|c|c|c|c|c|c|}
\hline & \multicolumn{2}{|c|}{$\begin{array}{c}\text { Local } \\
\text { Authority }\end{array}$} & \multicolumn{2}{|c|}{$\begin{array}{l}\text { Agricultural } \\
\text { Organisation }\end{array}$} & \multicolumn{2}{|c|}{ Total } \\
\hline & $\mathrm{N}$ & $\%$ & $\mathrm{~N}$ & $\%$ & $\mathrm{~N}$ & $\%$ \\
\hline & 139 & 64.5 & 64 & 35.5 & 203 & 100 \\
\hline \multicolumn{7}{|c|}{ GENDER } \\
\hline Male & 103 & 74.6 & 24 & 37.5 & 127 & 62.6 \\
\hline Female & 35 & 25.4 & 40 & 62.5 & 75 & 37.4 \\
\hline Total & 139 & 100 & 64 & 100 & 203 & 100 \\
\hline \multicolumn{7}{|c|}{ AGE (RECODED) } \\
\hline-3536 & 48 & 34.5 & 18 & 28.6 & 66 & 32.7 \\
\hline-45 & 45 & 33.4 & 24 & 38.0 & 69 & 34.2 \\
\hline $46+$ & 46 & 33.1 & 21 & 33.3 & 67 & 33.1 \\
\hline Total & 139 & 100 & 63 & 100 & 202 & 100 \\
\hline \multicolumn{7}{|c|}{ HIGHEST QUALIFICATION (RECODED) } \\
\hline Grade 12 or lower & 78 & 56.1 & 50 & 78.1 & 128 & 63.1 \\
\hline Diploma or certificate & 39 & 28.1 & 5 & 7.8 & 44 & 21.6 \\
\hline $\begin{array}{l}\text { Undergraduate or } \\
\text { higher degree }\end{array}$ & 22 & 15.8 & 9 & 14.1 & 31 & 15.3 \\
\hline Total & 139 & 100 & 64 & 100 & 203 & 100 \\
\hline \multicolumn{7}{|c|}{ HOME LANGUAGE (RECODED) } \\
\hline Afrikaans & 78 & 56.1 & 58 & 90.6 & 136 & 67.0 \\
\hline English & 34 & 24.5 & 4 & 6.2 & 38 & 18.7 \\
\hline Other & 27 & 19.4 & 2 & 3.2 & 29 & 14.3 \\
\hline Total & 139 & 100 & 64 & 100 & 203 & 100 \\
\hline \multicolumn{7}{|c|}{ TENURE (RECODED) } \\
\hline $1-4$ years & 21 & 15.2 & 18 & 28.1 & 39 & 19.3 \\
\hline $5-10$ years & 48 & 34.8 & 17 & 26.6 & 65 & 32.2 \\
\hline $11+$ years & 69 & 50.0 & 29 & 45.3 & 98 & 48.5 \\
\hline Total & 138 & 100 & 64 & 100 & 202 & 100 \\
\hline
\end{tabular}

\section{Statistical analysis}

The SPSS-programme was used to carry out the statistical analysis. Results were described and compared using means, standard deviations, skewness and kurtosis. The main measures of central tendency used were the mean and median. Table 2 indicates the skewness and kurtosis values for the subordinate - 
superior CHS (conflict-handling styles) as well as respondent peer CHS. The values are all very acceptable because in the case of skewness all statistics are equal or within the range of +3 to -3 and with the kurtosis +7 to -7 .

\section{TABLE 2}

DDESCRIPTIVE STATISTICS REGARDING CONFLICT-HANDLING STYLES FOR BOTH ORGANISATIONS IN TOTAL

\begin{tabular}{lcccccccc}
\hline & \multicolumn{3}{c}{ Sub-ordinate/Superior } & \multicolumn{5}{c}{ Sub-ordinate/Peer } \\
\hline Variable & Mean & Median & Skew. & Kurt. & Mean & Median & Skew. & Kurt. \\
\hline Q-1 & 1.92 & 2.00 & 1.552 & 2.171 & 1.74 & 2.00 & 1.595 & 3.782 \\
Q-2 & 2.07 & 2.00 & 1.139 & 0.578 & 2.25 & 2.00 & 0.935 & 0.331 \\
Q-3 & 2.74 & 2.00 & 0.434 & -1.166 & 2.87 & 2.50 & 0.100 & -1.309 \\
Q-4 & 1.84 & 2.00 & 1.383 & 1.935 & 1.87 & 2.00 & 1.608 & 3.791 \\
Q-5 & 1.73 & 1.00 & 1.777 & 3.214 & 1.76 & 2.00 & 1.074 & 2.080 \\
Q-6 & 2.82 & 2.00 & 0.201 & -1.349 & 2.87 & 2.00 & 0.180 & -1.273 \\
Q-7 & 2.07 & 2.00 & 1.196 & 1.193 & 2.14 & 2.00 & 1.247 & 1.406 \\
Q-8 & 3.37 & 4.00 & -0.457 & -1.004 & 3.54 & 4.00 & -0.546 & -0.877 \\
Q-9 & 4.04 & 4.00 & -1.095 & 0.464 & 3.75 & 4.00 & -0.961 & 0.151 \\
Q-10 & 2.13 & 2.00 & 1.074 & 0.769 & 2.45 & 2.00 & 0.856 & 0.171 \\
Q-11 & 2.57 & 2.00 & 0.604 & -0.719 & 3.05 & 3.00 & 0.018 & -0.956 \\
Q-12 & 1.79 & 2.00 & 1.658 & 2.445 & 1.83 & 2.00 & 1.541 & 3.340 \\
Q-13 & 2.49 & 2.00 & 0.683 & -0.491 & 2.70 & 2.00 & 0.445 & -0.696 \\
Q-14 & 2.27 & 2.00 & 1.011 & 0.700 & 2.21 & 2.00 & 1.182 & 1.296 \\
Q-28 & 1.78 & 2.00 & 1.654 & 3.387 & 1.76 & 2.00 & 1.345 & 3.084 \\
Q-15 & 2.09 & 2.00 & 1.222 & 1.075 & 1.93 & 2.00 & 0.299 & -1.148 \\
Q-16 & 2.65 & 2.00 & 0.329 & -1.176 & 2.80 & 2.00 & 0.195 & 1.180 \\
Q-17 & 2.59 & 2.00 & 0.339 & -1.228 & 2.79 & 2.00 & 0.087 & -1.353 \\
Q-18 & 2.96 & 3.00 & 0.108 & -1.301 & 3.06 & 3.00 & 0.331 & 0.962 \\
Q-19 & 2.42 & 2.00 & 0.828 & -0.023 & 2.74 & 2.00 & 0.740 & -0.479 \\
Q-20 & 2.56 & 2.00 & 0.598 & -0.723 & 2.48 & 2.00 & 0.777 & -0.335 \\
Q-21 & 2.48 & 2.00 & 0.576 & -0.706 & 2.40 & 2.00 & 1.072 & 1.121 \\
Q-22 & 1.90 & 2.00 & 1.419 & 2.234 & 1.92 & 2.00 & 1.518 & 3.828 \\
Q-23 & 1.92 & 2.00 & 1.438 & 2.288 & 1.91 & 2.00 & 0.748 & -0.203 \\
Q-24 & 2.02 & 2.00 & 1.293 & 1.457 & 2.48 & 2.00 & -0.715 & -0.392 \\
Q-25 & 3.68 & 4.00 & -0.820 & -0.233 & 3.61 & 4.00 & 0.247 & -1.163 \\
Q-26 & 2.96 & 3.00 & 0.100 & -1.300 & 2.87 & 2.00 & 0.435 & -0.963 \\
Q-27 & 2.68 & 2.00 & 0.423 & -1.049 & 2.69 & 2.00 & 1.654 & 4.345 \\
& & & & & & & & \\
\hline
\end{tabular}

\section{RELIABILITY}

The reliability of the questionnaire's applicable sections was determined by means of Cronbach-Alpha coefficient. According to Anastasi (1976) a desirable reliability coefficient would fall in the range of 0,80 to 0,90 . Nunnally \& Bernstein (1994) use 0,70 as a directive, whilst Bartholomew, Antonia \& Marcia (2000) argue that between 0,80 and 0,60 is acceptable.

TABLE 3

RELIABILITY ANALYSIS

\begin{tabular}{llccc}
\hline & Variable & $\begin{array}{c}\text { Cronbach's } \\
\text { Alpha } \\
\text { coefficient }\end{array}$ & $\begin{array}{c}\text { Kaiser- } \\
\text { Meyer-Olkin } \\
(\text { KMO) }\end{array}$ & $\begin{array}{c}\text { Bartlett's } \\
\text { Significance }\end{array}$ \\
\hline S & & & \\
U & Sub_1D Integrating & 0,84 & 0,85 & $<, 001$ \\
P & Sub_2 Avoiding & 0,81 & 0,80 & $<, 001$ \\
E & Sub_2D Dominating & 0,66 & 0,72 & $<, 001$ \\
R & Sub_3D Dobliging & 0,82 & 0,84 & $<, 001$ \\
I & Sub_4D Obliging & 0,62 & $<, 001$ \\
O & Sub_5D Compromising & 0,58 & & \\
R & $\quad$ & 0,82 & $<, 001$ \\
& $\quad$ Sub_1E Integrating & 0,90 & 0,79 & $<, 001$ \\
P & Sub & 0,74 & $<, 001$ \\
E & Sub_2E Avoiding & 0,82 & 0,81 & $<, 001$ \\
E & Sub_3E Dominating & 0,71 & 0,70 & $<, 001$ \\
R & Sub_4E Obliging & 0,80 & & \\
S & Sub_5E Compromising & 0,66 & & \\
\hline
\end{tabular}

The reliability of ten constructs as shown in table 3 measured by the Cronbach-Alpha was also confirmed by means of the KaiserMeyer-Olkin measure of sampling adequacy and Bartlett test of sphericity. The overall average of the Cronbach-Alpha is 0,76 which clearly falls within the range of directives. The KMOmeasure for adequacy was 0,77 indicating that the sample was adequate and the Bartlett test of sphericity yielded a statistical approximate chi-square $(\mathrm{p}<0.001)$, which also indicated the probability that the correlation matrix had significant correlation amongst the variables.

\section{RESULTS}

Results on the CHS respondents toward superiors

In the first part of the study it was determined which different CHS were predominantly used between the respondent and his superior in relation to the background variables. In order to achieve this objective it had to be determined whether a significant statistical difference was present regarding each variable by means of independent sample tests and variance analysis (ANOVA), i.e. whether $p<0,05$ which would confirm the presence of a significant statistical difference (Howell, 1995). By comparing the different CHS against the different variables the following analysis of results can be made (refer table 4 and table 5 ).

TABLE 4

Significant DifFerence (P - VALUE) REGARDING DIFFERENT BACKGROUND VARIABLES

\begin{tabular}{|c|c|c|c|c|c|c|c|c|c|c|c|}
\hline \multirow{2}{*}{$\begin{array}{l}\text { Variables } \\
\text { CHS }\end{array}$} & \multicolumn{3}{|c|}{ Gender } & \multirow{2}{*}{$\frac{\text { Age }}{\text { La }}$} & \multicolumn{5}{|c|}{ Qualification Language } & \multicolumn{2}{|c|}{ e Years service } \\
\hline & & $\mathrm{La}$ & Ac & & Ac & La & Ac & La & Ac & La & Ac \\
\hline \multirow[t]{2}{*}{ Integrating } & $\mathrm{s}$ & 0.783 & 0.169 & 0.276 & 0.150 & 0.783 & 0.730 & 0.683 & - & 0.631 & 0.211 \\
\hline & $\mathrm{P}$ & 0.832 & 0.913 & 0.570 & 0.315 & 0.399 & 0.256 & 0.495 & - & 0.028 & 0.424 \\
\hline \multirow[t]{2}{*}{ Avoiding } & S & 0.005 & 0.627 & 0.948 & 0.654 & 0.120 & 0.263 & 0.420 & - & 0.303 & 0.571 \\
\hline & $\mathrm{P}$ & 0.068 & 0.119 & 0.996 & 0.500 & 0.046 & 0.230 & 0.978 & - & 0.250 & 0.244 \\
\hline \multirow[t]{2}{*}{ Dominating } & S & 0.780 & 0.498 & 0.340 & 0.567 & 0.246 & 0.237 & 0.005 & - & 0.918 & 0.185 \\
\hline & $\mathrm{P}$ & 0.638 & 0.696 & 0.424 & 0.050 & 0.306 & 0.127 & 0.317 & - & 0.943 & 0.260 \\
\hline \multirow[t]{2}{*}{ Obliging } & S & 0.567 & 0.309 & 0.175 & 0.024 & 0.004 & 0.480 & 0.000 & - & 0.408 & 0.019 \\
\hline & P & 0.420 & 0.292 & 0.046 & 0.381 & 0.040 & 0.417 & 0.003 & - & 0.070 & 0.778 \\
\hline \multirow[t]{2}{*}{ Compromise } & $S$ & 0.806 & 0.766 & 0.049 & 0.091 & 0.598 & 0.258 & $\begin{array}{ll}3 & 0.570\end{array}$ & - & 0.048 & 0.080 \\
\hline & $\mathrm{P}$ & 0.886 & 0.341 & 0.740 & 0.641 & 0.806 & 0.301 & 0.113 & - & 0.069 & 0.144 \\
\hline
\end{tabular}

CHS = conflict-handling styles

$\mathrm{La}=$ local authority

$\mathrm{Ac}=$ agricultural company

$\mathrm{S}=$ respondent/superio

$\mathrm{P}=$ respondent $/$ peer

TABLE 5

DESCRIPTIVE STATISTICAL MEAN ON HANDLING STYLES ACCORDING TO DIFFERENT BACKGROUND VARIABLES

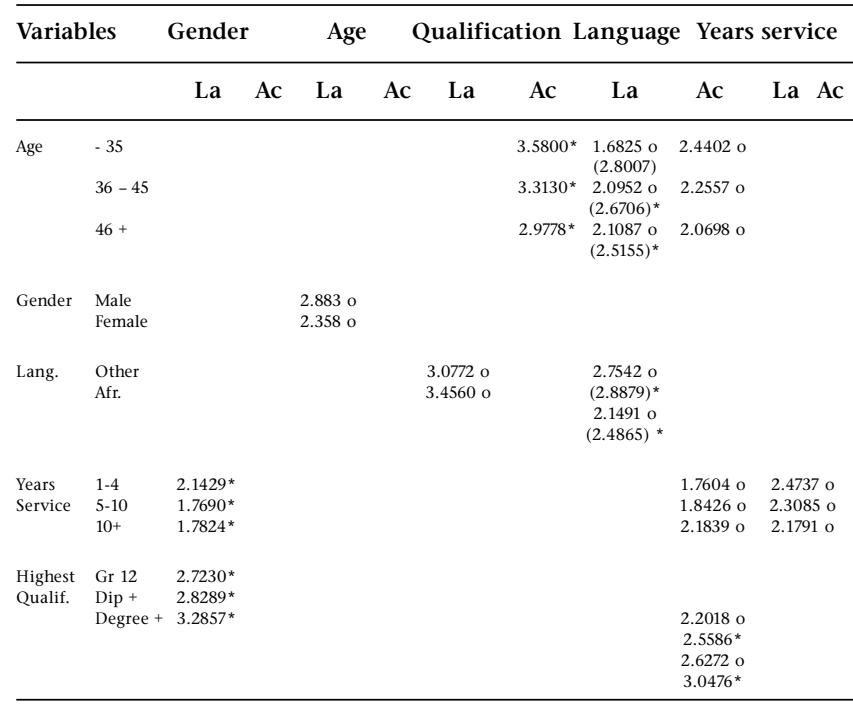

$\mathrm{Ac}=$ Agricultural company

$\mathrm{La}=$ Legal authority

$\mathrm{La}=$
$*=?$
$0=?$ 
Regarding 'gender' a statistical difference was found $p=0,005$ within the variable avoiding for the local authority. By looking at the group statistics of recordings it shows that after the avoiding CHS was indicated as the only style where a statistical difference was found, it can be stated that the female respondents $(\mathrm{M}=2,3578)$ tended to apply this handling-style when in conflict with their superiors more than the male respondents $(M=2,8883)$. No meaningful statistical difference were recorded for the agricultural company.

Comparing the different CHS against the background variable "age" the following results were obtained. A meaningful significant statistical difference was found $(p=0,049)$ within the variable compromising for the local authority. Respondents younger than 35 years had an average mean of 2,4402 , whilst 36 - 45 years had a mean of 2,2557 and those older than 45 years a mean of 2,0698. This illustrates that the older the respondents are, the more positive they are to use compromising as a CHS in comparison with the other four CHS's. In the case of the agricultural company the statistical difference was ( $\mathrm{p}=$ $0,024)$ regarding the variable obliging. Consulting the descriptive statistics in table 5 it shows that the younger respondents ( -35 years) tended to be more obliging than the groupings $36-45$ years and $46+$ years $(M=1,6852, M=2,0952$ and 2,1087 respectively).

The highest qualification as a background variable in local authority indicated a $p=0,004$, thus verifying that obliging is the only handling style where a difference in the frequency with which this style is used, can be found. A grade qualification equal to or less than grade 12 had an $M=2,2018$. Respondents in possession of a diploma/certificate $\mathrm{M}=2,6272$ and a degree or higher had an $M=2,7937$. No meaningful statistical difference could be found in any of the variables with regard to the agriculture company.

Comparing the different CHS's against the background "homelanguage" presented the following results for the local authority. $p=0,0005$ within the variable dominating verified it as a CHS with a significant difference in the degree to which this style is used. Secondly a significant statistical difference was found within the variable obliging $(\mathrm{p}=0,0000)$. The $M=3,0772$ (English + African language) and $M=3,4560$ (Afrikaans) showed less dominance by the latter group and being more obliging $\mathrm{M}=2,1491$. The low number of respondents in the agricultural company resulted in a non-statistical analysis.

A significant statistical difference $(p=0,048)$ and $(p=0,019)$ was found, within the variable compromising and obliging for the background variable, "years in service" for both the local authority and the agricultural company. For the grouping 1-4 years, 5-10 years, and more than 10 years for the local authority the means were $M=2,4737, M=2,3085$ and $M=2,1791$. In the case of the agricultural company the means recorded were $\mathrm{M}=$ $1,7604, \mathrm{M}=1,8426$ and $\mathrm{M}=2,1839$.

\section{Results on CHS respondent to peers}

After determining which CHS was used to a greater extent than the others in a conflict-situation between the respondent and his supervisor, it was decided to establish handling-styles when conflict occurred between respondent and peer.

The background variable "different genders" showed that no meaningful statistical differences could be found in both participating organisations. Exploring the background variable "different age groups" a statistical difference $(p=0,046)$ was found within the variable obliging for the local authority. Means recorded here were -35 years $(M=2,8007)$, 35-45 years $(M=$ $2,5706)$ and $45+$ years $(\mathrm{M}=2,5155)$. The agricultural company had a statistical difference $(\mathrm{p}=0,050)$ within the variable dominating for different age groups. Means for the age groups were -35 years $(M=3,5800), 36-45$ years $(M=3,3130)$ and $45^{+}$ years $(\mathrm{M}=2,9778)$.

When considering highest qualification as a background variable statistical significant differences within the variable avoiding $(\mathrm{p}$

\begin{tabular}{lcc}
\hline M-values & Loc. Auth. & Agric. Co \\
\hline Integrating & 1,948753 & 1,847798 \\
Avoiding & 2,753086 & 2,604872 \\
Dominating & 3,292424 & 3,655556 \\
Obliging & 2,41658 & 1,924572 \\
Compromising & 2,257463 & 2,201613 \\
\hline
\end{tabular}

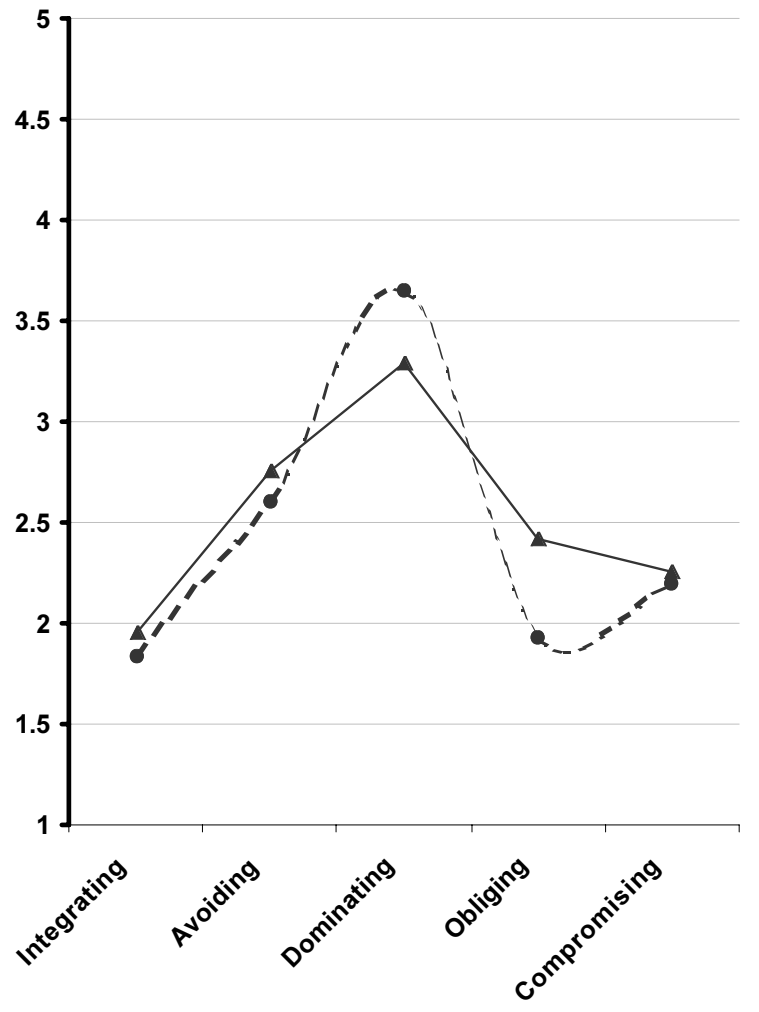




\begin{tabular}{lcc}
\hline M-values & Loc. Auth. & Agric. Co \\
\hline Integrating & 1,825994 & 1,728673 \\
Avoiding & 2,890836 & 2,717742 \\
Dominating & 3,253333 & 3,387652 \\
Obliging & 2,662879 & 2,486772 \\
Compromising & 2,217803 & 2,139344 \\
\hline
\end{tabular}

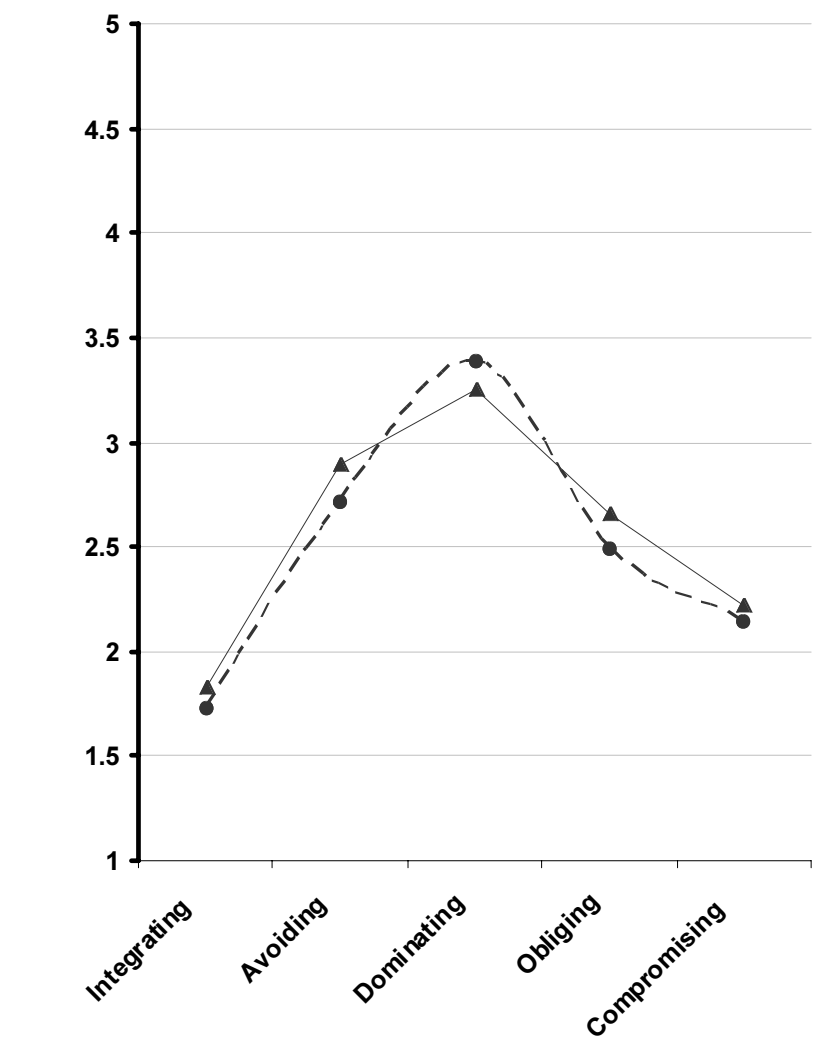

$\_$Local Authority

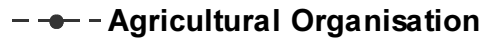

Figure 2: Comparative analysis of conflict with peer in both organisations

$=0,046)$ and obliging $(p=0,040)$. These two CHS when compared to the background variable revealed a difference with which it is used by respondents of a local authority. Means according to highest qualification grouping were $\mathrm{M}=2,7230, \mathrm{M}=2,8289$ and $\mathrm{M}=3,2857$ for avoiding and $\mathrm{M}=2,5586, \mathrm{M}=2,653$ and $\mathrm{M}=$ 3,0476 for obliging respectively. In the agricultural company no meaningful statistical difference could be found.

With regard to "home-language" for the local authority a difference of $(p=0,003)$ within obliging was found. The mean for the Afrikaans group was $M=2,8879$ and other languages as a group, $\mathrm{M}=2,4865$. The low number of agricultural company respondents resulted in a non-analysis.

A meaningful significant statistical difference $(p=0.028)$ within the variable integrating, for the local authority, thus verifying that this is the only CHS in which a difference in frequency with which this style is used, can be found. Respondents working for 1-4 years had an $\mathrm{M}=2.1429,5-10$ years, $\mathrm{M}=1.7690$ and $11+$ years, $\mathrm{M}=1.7824$. No meaningful statistical difference could be found in the variables for the agricultural company.

\section{DISCUSSION}

When comparing the difference in the CHS as used by respondents toward superiors for both organisations it can be seen in figure 1 that all styles had a variation in frequency and each one is used when compared to the different sections. The style that differed the most after comparing the different sections within the local authority, was the obliging CHS. In the agricultural company it was used to a much lesser extent $(\mathrm{M}=$ $2,31358)$ than was the case in the local authority $(M=1,92457)$.

The integrating style which had an $\mathrm{M}=1,8411$ in the agricultural company and $\mathrm{M}=1,9487$ in the local authority was used to the greatest extent. The dominating style was used the least in both organisations.
With regard to CHS between respondents and peers (figure 2) all styles had a variation in terms of frequency. Here also the integrating style was recorded as being used to the largest extent in both organisations with means of 1,8259 and 1,72867 . The dominating style, as in the case of subordinate-superior was also used least in conflict situations in both organisations.

Conclusions that can also be drawn from the study are that in the local authority female respondents tend to use avoiding style more with their superiors. Older employees also tend to be more compromising than younger ones. Using this style involves giveand-take whereby both parties give up something to make a mutually acceptable decision (Rahim, 2002). In the agricultural company it was found that the younger employees were proned to make more use of the obliging style in a conflict situation with their superiors. However, when involved in conflict with their peers it was the opposite. Here younger persons were less obliging than the older employees. Older respondents tended to be more dominating toward their peers in the agricultural organisation. This was not the case in the local authority. It should be remembered that dominating, sometimes also referred to as forcing (Euwema, Van de Vliert \& Bakker, 2003), considered to be the least effective CHS stimulates and escalates conflict, hinders conflict resolution, increase frustration and may result in more aggression and increase in future conflict (Meyer, 2004). Van de Vliert, Euwema \& Huismans (1995) believe that the dominating style was less effective when used by supervisors (superiors) with their subordinates.

Qualifications also seem to play a definitive role in usage of specific conflict-handling styles. The higher the respondents were qualified and intellectually more advanced the less they were obliging toward their superiors in the local authority. This was not the case in the agricultural company. Where peers were in conflict statistical differences also revealed that respondents with higher qualifications also became less obliging in conflict situations in the local authority. In the agricultural company there was no difference recorded. 
Considering the years of service it seemed that there was some form of correlation with age in the local authority. Respondents with long years of service and age were more compromising and obliging with their superiors. Compromising has an intermediate concern for self and others (Rahim, 2002) with respondents endeavouring to find a middle ground in a conflict situation between themselves and their superiors. Older respondents of the local authority were also more obliging toward peers in conflict-situations. In both cases, respondent to superior and respondent to peer it was recorded that Afrikaans-speaking respondents made more use of obliging CHS in conflict situations.

\section{CONCLUSION}

As an initial exploration in the field of comparison of conflicthandling styles between a private and public sector organisation it is believed that the main objective of this study, namely to determine whether there exists a significant difference in the handling of interpersonal conflict, was achieved.

Limitations to the study were in the first instance, that the two participating organisations differ in the sense that the public sector-organization has already complied to a large extent with transformation and affirmative action programmes and the agricultural company not. The distribution of race, culture and language groups were not even. Limiting the study to only two institutions means that the findings can not be generalized. Due to the relative complexity of the questionnaire and the ability of all employees to complete it, the survey had to be restricted to job-levels that eliminated the lower ranks of the workforce. Studying the lower job-levels may prove different conflict handling styles being used by them in interpersonal conflict situations.

\section{REFERENCES}

Anastasi, A. (1976). Psychological testing. New York. MacMillan.

Bartolomew, K., Antonia, J.Z. \& Marcia, J.E. (2000). Coded semistructured interviews in psychological research. In H.T. Resi $\&$ C.M. Judd. Handbook of research methods in social and personality psychology. Cambridge. Cambridge University Press. 286-312.

Bodtker, A. M. \& Jameson, J.K. (2001) "Emotions in conflict formation and its transformation: Application to organisational conflict management." International Journal of Conflict Management 12 (3): 223-226

Euwema, M.C., Van de Vliert, E. \& Bakker, A. (2003) "Substantive and relational effectiveness of organizational conflict behaviour." The International Journal of Conflict Management. 14 (2): 119-139

Emory, C.W. \& Cooper, D.R. (1991) Business research methods. New York: Richard D. Irwin.

Hair, G.F., Anderson, R.E. et. al. (1995) Multivariate data analysis: With readings. Englewood Cliffs, New Jersey: Prentice-Hall.
Howell, D.C. (1995) Fundamental statistics for behavioural sciences. Wadsworth Publishing Company: Balmont, California.

Jehn, D.A. (1997) A qualitative analysis of conflict types and dimensions in organization groups. Administrative Science Quaterly. 42: 530-557

Mastenbroek, W.E.G. (1993) Conflict management and organizational development. New York: John Wiley and Sons.

Meyer, S. (2004) Organizational response to conflict: Future conflict and work outcomes. Social Work Research. 28 (3): 183-190.

McNamara, P.L. (2003) Conflict resolution strategies. Office PRO. Aug/Sept.

Nelson D \& Quick J (2001) Organizational behaviour: Foundations, realities and challenges. Cincinnatti: SouthWestern College Publishing.

Nunnally, J.C. \& Bernstein, I.H. (1994), Psychometric theory. New York. McGraw-Hill.

Opotow, S. (2000) Aggression and violence. (In: Deutsch, M. and Coleman, P. T.) The handbook of conflict resolution. San Fransisco: Jossey-Bass Publishers.

Pelled, L.H., Eisenhardt, K.M. \& Xin, K.R. (1999) Exploring the black box: An analysis of group work diversity, conflict and performance. Administrative Science Quaterly. 44: 1-28

Rahim, M.A. (1986) Referent role and styles of handling interpersonal conflict. The Journal of Social Psychology. 7 (2): 144-153.

Rahim, M. A. (1992) Managing conflict in organizations. New York: Praeger

Rahim, M.A. (2002) "Toward a theory of managing organizational conflict" The International Journal of Conflict Management. 13 (3) 206-235.

Rahim, M.A. \& Bonoma, T.V. (1979) Managing organizational conflict: A model for diagnosis and intervention. Psychological Reports. 44

Rahim, M.A. \& Magner, N.R. (1995) Confirmatory factor analysis of the styles of handling interpersonal conflict: First-order factor model and its intervariance across groups. Journal of Applied Psychology. 80: 122-132.

Robbins, S. P., Odendaal, A. and Roodt, G. (2003) Organisational behaviour: Global and South African Perspectives. Cape Town: Pearson Education Inc.

Schermerhorn, R. (1999) Management. New York: John Wiley.

Thomas, K.W. \& Killman, H.R. (1974) Thomas-Killman conflict MODE instrument. New York: Xicom.

Thomas, K.W. \& Killman H.R. (1976) Conflict and conflict management." (In Dunette, M.D. (ed.) Handbook of Industrial Organizational Psychology. Chicago: Rand McNally.

Tjosvold, D. \& Chia, L.C. (1988) "Conflict between managers and workers: The role of cooperation and competition. Journal of Social Psychology. 129: 235-247.

Van de Vliert, E., Euwema, M.C. \& Huismans, S.E. (1995) Managing conflict with a subordinate or a superior: Effectiveness of conglomerate behaviour. Journal of Applied Psychology. 80: 271-281.

Van de Vliert, E \& Kabanoff, B. (1990) Toward theory-based measures of conflict management, Academy of Management Journal. 33:199-209 